\title{
"Donki" Migration of Refugees from South Asia to Greece
}

\author{
Mohammed Taukeer ${ }^{1}$
}

\begin{abstract}
This article focused on the study of irregular "Donki" migration of refugees from South Asia to Greece in Europe. The study is based on the field survey which was conducted in August 2017 in Athens, Greece. The primary data was collected by method of qualitative study design. The finding of study show that "Donki" migration is associated with unauthorised migration of refugees from South Asia to Europe due to hopes of better life in Europe compared to South Asia. The "Donki" migration is synonyms with the hurdles and bravery in the views of South Asian refugees because South Asian refugees face political, economic and geographical challenges with psychological distress in the entire journey of migration from South Asia to Europe. This study encourages academics, researchers and policy makers to understand the meaning, determinants and consequences of "Donki" migration. It is hoped to be useful for better policies for management of the challenges faced by South Asian refugees in Europe.
\end{abstract}

Keywords: "Donki" migration; irregular migration; South Asians; Greece; Europe

\section{Introduction}

"Refugees are persons who, owing to a well-founded fear of being persecuted for reasons of race, religion, nationality, membership of a particular social group or political opinion. They are outside of their country of nationality and are unable or, owing to such fear, are unwilling to avail themselves of the protection of that country. Persons recognized as refugees under this definition are sometimes called convention refugees and are usually granted an openended per- mission to stay in the country of asylum" (Bilsborrow et al., 1997:38). Following to the resolution of the United Nation, Universal Declaration of Human Rights in December 1948 and the organization held the Conference on the Status of Refugees and Stateless persons on May 28, 1951. The convention adopted on July 28, 1951 under General Assembly Resolution 429(V) which created the United Nation High Commissioner for Refugees (UNHCR) regarding ensure to the rights of refugees across the globe (UNHCR, 1995:6-7). By the end of year 2018, there were total of 25.9 million refugees globally included to 20.4 million under United Nation High Commission for Refugees (UNHCR) and 5.5 million refugees registered by the United Nations Relief and Works Agency for Palestine Refugees in near east (UN RWA) (McAuliffe, 2020:39). On 19 September 2016, the General Assembly held a high-level meeting regarding address to the large movements of refugees and migrants, which know as New York Declaration for Refugees and Migrants. In this declaration, member states committed about to give protection to the human rights of refugees and migrants. Apart, declaration contains a set of commitments that apply to both refugees and migrants under the sustainable agenda for development 2030 for reduce to discriminations against refugees and migrants (UNDESA, 2020:25). On the basis of above short concise description,

\footnotetext{
${ }^{1}$ Mohammed Taukeer is former research scholar in G B Pant Social Science Institute, University of Allahabad and presently associated as research fellow in International Institute of Migration and Development, Trivandrum, Kerala, India. E-mail: taukmd@gmail.com.
} 
the section of review of literature is based on the earlier studies about determinants and consequences of migration of refugees from Asian countries to European countries. The selected review of literatures provided a platform for understand to the meaning, determinant and consequence of Donki migration of refugees from south Asia to Europe because illegal Donki migration is emerging issue for Asian and European countries.

\section{Understanding "Donki" migration}

Countries of European Union are emerged as hotspot for refugees of Asian countries especially from Muslim countries namely- Syria, Afghanistan, Iraq due to political instability in these countries (Stevens, 2017:185). Asian refugees illegally cross to the international borders of European countries as well as avoid to the border security procedures of registration and identification. These consequences are generating a situation of fear and instability on the borders of European countries (Nedoh, 2017:18). Turkey is the main route for migration of refugees from Asian countries to European countries. There is long history of migration from Turkey to European countries in the context of socio-economic and geographical connection between Turkey and European countries. (Kesici, 2021:187-188). Turkey works as transit destination for illegal migration from Asian countries to Greece because Turkey is the neighbouring countries of Greece (Eren, 2019:125). These illegal refugees are producing political and economic problems for both Turkey and Greece (Dogutas, 2019: 113). Both Turkey and Greece are facing socio-economic and political problems for managing to challenges of illegal migration from Asia to Europe (Rygiel et al., 2016:316).

Countries of European Union are facing political and economic pressure due to huge flow of refugees from Asia. These consequences are leading to the violence in European countries because refugees are entering in the job markets of Europe. As a result, these phenomena are generating a conflict between Europeans and Asian refugees because these refugees and asylum-seekers are not being easily accepted by Europeans (Hatton \& Williamson, 2006:249284). Asian refugees face extreme experiences like political persecution, pain and long journey of migration with deprivation and loss. These kinds of experiences are creating problems of identity and lack of sense of emotional attachment with host societies in Europe (Ligabue, 2018: 167). The consequences of statelessness are leading to the deprivation from basic human rights because refugees face discrimination in rights to work, health care and education related rights. It also leads to vulnerability in human rights violation of refugees in European countries (Foster \& Lambert, 2016: 584). Matters of social and economic integration are very complex and difficult issues before Asian refugees in Europe because refugees find themselves isolated among Europeans (Robila, 2018:10). These refugees and asylum seekers are facing problem of identities among Europeans because Europeans feels hesitation accept to the integration of Asian refugees in the main discourse of European culture (Gale, 2004: 321-340). Asian refugees developed a strong social bonding with Asian community in Europe because social network system of refugees provide a social and economic space to Asian refugees for adjust in the culture of Europe as well as minimise the socio-economic and psychological risk of illegal migration in Europe (Lamba \& Krahn, 2003:355-356).

The problem of refugees is emerged as economic challenges for European countries because huge flow of Asian refugees and asylum-seekers are creating a pressure on economy of European countries (Aiyar et al., 2016:40). The crisis of refugees is emerged as European crisis

Border Crossing 
due to huge flow of refugees from Syria, Afghanistan, Somalia and Iraq. Across Europe and especially in the countries of European Union have divergent interpretation of this process. Crisis of refugees is leading various kinds of concept likes-humanitarianism, security and diversity related problems in countries of European Union (Krzyżanowski et al., 2018:1).

European countries should start a comprehensive dialogue for rethinking about managing to challenges of assimilation and integration of refugees in Europe with human centric approach for secure the welfare and rights of refugees in Europe (Barslund et al., 2019: 4). The process of global governance for multiple decision making process are capable about manage to challenges of refugees in European countries (Obokata, 2010: 123). There is required to start thinking about global sociological theory of migration because issues of refugees are the subject matter of social well being for European countries (Richmond, 2018:7).

The review of literature shows that matters of illegal migration of refugees are creating social, political and economic challenges for Turkey and European countries. Asian refugees are facing problems socio-economic problems with deprivation from basic human rights in European countries. In these consequences, present paper explores the meaning, determinant and consequence of illegal Donki migration from South Asia to Greece in Europe as well as tries to fill the gap of literature about study of illegal Donki migration. In these consequences, the field work was conducted in August 2017 at parks, metro stations and South Asian restaurants in Omonia square of Athens. The primary data was collected by qualitative study design through help of informal interview, focus group interview and method of participant observation among total 150 South Asian refugees under the saturation stage of information of qualitative study design. The sampling of the selection of South Asian refugees was determined by snow ball and accidental sampling. The findings of the study is analysed by narratives, oral history and case study for better interpretation of the meaning, determinants and consequences of Donki migration of South Asian refugees in Europe.

\section{Meaning and Determinants of "Donki" Migration}

The meaning of Donki is slow, blunt but this term is associated with the illegal migration of refugees from South Asia to Europe. The entire process of illegal migration knows as Donki migration among South Asian refugees, those illegally migrate to Europe via route of Iran and Turkey. The entire process of illegal Donki migration starts from Pakistan due to its closest geographical connection with Iran and Turkey because it is most favourite route of illegal migration among South Asian refugees. Illegal South Asian migrants migrate from Pakistan to Greece via route of Iran and Turkey. Term of Donki is the label of self-respect and honour in the view of South Asian refugees because they tolerate geographical, political and psychological barriers in the entire journey of illegal Donki migration. The story of the Donki migration is synonyms of pain, emotion, courage and bravery in the view of South Asian refugees. It is found that term of Donki is the narrative and description of endless journey of illegal migration of South Asian refugees as well as represents socio-economic and geographical identity of South Asian refugees in Europe. These South Asian refugees migrate with positive attitudes because they expect opportunities of better life in Europe compared to South Asian countries. The positive attitude of South Asian refugees leads to their victory on the risks and barriers of illegal migration from South Asia to Europe.

These South Asian refugees told that they migrated with help of human trafficking network because they were unable to complete necessary required documentation process for legal 
migration in Europe. Hence, they contacted to agent of human trafficking networks, who provided them a specific route of illegal migration from Pakistan to Greece via route of Iran and Turkey. These South Asian refugees crossed to sea, rivers, forests, mountains and deserts in the entire route of illegal migration from Pakistan to Greece. These refugees completed their travel in two and half month journey of migration by foot, riding on boats and trucks. These South Asian refugees faced socio-economic and psychological distress because agents of human trafficking network mentally and economically exploited to these South Asian refugees in Iran and Turkey. These South Asian refugees further told that they had not any option to return to their homeland because they illegally entered in Greece without any valid travel documents. They told that they migrated on the way of endless journey of migration because they had only option to moving forward in Europe. ${ }^{2}$

"We are Donki"- it is also observed that term of Donki led to the social and economic bonding among South Asian refugees in Greece because they were not Pakistanis and Bangladeshis in Greece because term of Donki gave them homogenous socio-economic and geographical identity of South Asia among Europeans. These South Asian refugees had a great respect for Europeans because Europeans gave them a space in the life of Europe. These illegal South Asian refugees were interested in migration to France, Germany and Britain but they were not ensured about next journey of illegal migration from Greece to Western Europe due to political and geographical barriers in the route of illegal migration from Greece to Western European countries. These South Asian refugees told that they searched the opportunities for migration in Western Europe through help of human trafficking network because they faced problems to getting status of convention refugees under the provisions of United Nation, High Commission for Refugees (UNHCR) in Greece. These circumstances led to the illegal migration from Greece to France, Germany and Britain because South Asian refugees considered Western Europe as better destination compared to Greece. ${ }^{3}$

Both economic and non-economic factors determined the process of illegal migration from South Asia to Greece because they illegally migrated due to hope of better opportunities of life in Europe compared to precarious economic conditions of South Asia. There was well developed social network system in the Donki migration from Pakistan to Greece in Europe. The social network system minimised the risk of migration as well as provided socioeconomic and psychological support to illegal migrants in the entire journey of illegal migration from Pakistan to Greece. South Asian refugees developed a social bonding with south Asian community in Greece. The social bonding attracted to the South Asians in Greece because Greece worked as gate way for migration to Western Europe. It is observed that role of information technology was so crucial in the exchange of information about illegal migration from Greece to South Asia. Therefore, these circumstances gave a dream to South Asian migrants to gain a better life in the glamour of European countries. ${ }^{4}$

It is case study of 26 years old Roshan who was Bangladeshi citizen, worked in Saudi Arabia. He told that Kafeel (Sponsor) mentally and physically exploited him as well as retained his

\footnotetext{
2 The information is based on the focus group interview of south Asian refugees at parks of Omonoia square in Athens on 23/08/2017.

${ }^{3}$ The information is based on the focus group interview of south Asian refugees at south Asian restaurant named Roti- Boti restaurant in Athens on 23/08/2017.

${ }_{4}$ The information is based on the informal interview of south Asian refugees at parks of Omonoia square in Athens on
} $23 / 08 / 2017$.

Border Crossing 
passport. He told that Kafeel (sponsor) used to hold salaries; hence he faced a panic conditions in their working and living circumstances in Saudi Arabia. He had not any option to return to Bangladesh because Kafeel (sponsor) refused to give his passport. Finally, he decided to migrate in Europe through help of human trafficking network. He paid 15,000 Riyal (currency of Saudi Arabia) to agent of human trafficking network for illegal migration to Greece via route of Iran and Turkey. He further told that agent of human trafficking network demanded extra money in Turkey as well as mentally exploited to him during journey of illegal migration. He completed his travel by foot, riding on trucks and boats. He crossed to desserts, forest, valley, rivers and sea in the entire journey of illegal migration. He reached to Greece in two months journey of migration but he was arrested by police on the border of Greece. Finally, he was two years in jailed in Greece. He gave application for getting status of refugee and got status of convention refugees in Greece. He told that he had a dream of gain better life in Europe. He had great respect and honour for Greece because he considered that experiences of jobs and migration could be opened the doors of migration from Greece to Western European countries. ${ }^{5}$ Another case study is story of 20 years old Majid who was Pakistani citizen. He told that he migrated from Pakistan to Greece due to lack of opportunity of employment in Pakistan. He gave application in the embassy of Greece in Pakistan for getting work permit visa of Greece but he was failed. Finally, he decided to migrate to Greece through Donki route of migration via route of Iran and Turkey. He paid 500000 Pakistani rupees to agent of human trafficking network for illegal migration to Greece. He travelled in the group of illegal migrants and crossed deserts, forests, valleys, rivers and sea. Finally he reached in Greece in two and half month of journey of migration from Pakistan. He was also mentally and economically exploited by agent in both Iran and Turkey. Majid also got status of convention refugees by UN HCR and he worked as sweeper in South Asian restaurant in Athens. He had dream for migration to Western Europe because he considered Western Europe as land of dream due to availability of the better economic opportunities compared to Greece. He was also humble and respectful about Europeans because Europeans provided him a platform for achieved the better economic opportunities in Greece. ${ }^{6}$

\section{Consequences of "Donki” Migration of Refugees in Greece}

South Asian refugees used to take amusement of their life in Athens because they felt bravery as Donki migrants due to defeated to the geographical and political barriers in journey of illegal migration from South Asia to Europe. South Asian refugees were strongly associated to each other because they felt themselves as brave Donki migrants in Greece. They proudly said that "They were Donki", this term created a unity among South Asian refugees in Greece. This positive approach gave them a power regarding to adjusting themselves in the culture of Europe. These illegal South Asian refugees faced problems of identities before immigration authorities of Greece for getting to the status of convention refugee because they had not passport and other valid travel documents. Hence, these illegal South Asian refugees were being identified by their native languages likes Urdu language represented to Pakistani refugees while Bangla language represented refugees of Bangladesh in Greece. They told that immigration authority used takes help of language moderators for interact to illegal South

\footnotetext{
5 The case study is based on the informal interview of south Asian refugee named Roshan at park of Omonoia square in Athens on $23 / 08 / 2017$.

${ }^{6}$ The case study is based on the informal interview of south Asian refugee named Majid at Roti Boti restaurant of Omonoia in Athens on 23/08/2017.
} 
Asian refugees for identify to their national identity. The moderator interacted to these illegal South Asian refugees in their native languages like Urdu and Bangla. Therefore, language was the major tool for identification of national and cultural identity of illegal South Asian refugees in Greece. ${ }^{7}$

South Asian refugees told that they filed an application for getting status of convention refugees in Greece. They remained in the status of asylum-seekers until their application is considered and adjudicated as refugees. These South Asian refugees faced many problems to get status of convention refugees. These refugees expressed that they migrated in Europe with hope of better future but they faced so many hurdles in the process of adjustment in the working and living conditions in the life of Europe because these South Asian refugees unwillingly proved their socio-economic and political identity among Europeans. These South Asian refugees were not easily accepted by Europeans due to unanswered question of political and economic identities of South Asian refugees. ${ }^{8}$

It is observed that South Asian refugees were working and living in Greece under monitoring of United Nation High Commission for Refugees (UNHCR). South Asian refugees were working in restaurants, shopping malls, motor garages and as manual labourers in industries and agriculture sector in Greece. These South Asian refugees were properly monitored by UNHCR. They told that NGOs and south Asian community were providing socio-economic and psychological support to South Asian refugees because South Asian refugees faced panic conditions due to long geographical distances from their homeland in South Asia. Apart, South Asian community and NGOs were providing an important role in searching jobs for South Asian refugees in Greece. There was well developed social bonding among South Asian refugees in Greece. This social bonding was providing a platform to South Asian refugees for their adjustment in the culture of Europe. These refugees felt happiness and satisfaction in the working conditions of Greece because both UNHCR and authority of Greece provided socio-economic and psychological support to South Asian refugees. It is observed that there was huge presence of south Asian refugees, those were illegally working in Greece with help of south Asian community of Greece. These illegal South Asian refugees worked illegally in very low wage rate compared to convention refugees; those were working in better working conditions under monitoring of UNHCR. The illegal South Asian refugees worked and lived in very precarious working conditions in Greece because they did not have regular jobs because they had not any skills and jobs based certificate. ${ }^{9}$

It is case study of 26 years old south Asian refugee named Afjal, who was of citizen of Bangladesh. He had work permit paper of UNHCR for work as convention refugee in Greece. He worked as manual labourer in cotton textile industry in Athens. He earned 40 Euro per six hour in day. Afjal told that he was satisfied about working conditions of Greece because UNHCR regularly monitored to his working conditions. He also told that he was not interested to return Bangladesh because he had dream of migration to developed Western

\footnotetext{
${ }^{7}$ The information is based on the focus group interview of south Asian refugees at metro station and parks of Athens on 24/08/2017.

${ }^{8}$ The information is based on the focus group interview of south Asian refugees at parks of Omonoia square in Athens on 24/08/2017.

${ }^{9}$ The information is based on the observation of the working conditions of south Asian refugees with focus group interview at shops, parks and metro station in Athens on 24/08/2017.
} 
Europe. ${ }^{10}$ Another case study is about 25 years old named Ahamad, who was also citizen of Bangladesh and he did not apply the application for getting status of convention refugee. As a result, he used to work as illegal refuge in Athens. He told that he did not find job regularly. He told that he slept hungry in two to three nights in every week because he did not find regular jobs but south Asian community provided support for surviving in Athens. He was searching a chance to cross the border of Greece for enter in Italy due to availability of the better opportunities of jobs compared to Greece. ${ }^{11}$

It is observed that there was socio-economic coherence and integration between South Asian refugees and Europeans due to participation of South Asian refugees in the socio-economic development of Greece. These consequences were developing social integration in the economic behaviour of South Asian refugees in Greece. The economic behaviour of South Asian refugees determined their participation in the job market of Greece because South Asian refugees were working in the service sector of Greece according to demand of skills in Greece. The economic activities of South Asian refugees were creating the economic identities of South Asian refugees as skilled labourers among Europeans. These consequences were transforming the identity South refugees into skilled labourers in the job market of Greece. These refugees were also self-employed because they had their own shops of electronic materials, food shops, restaurants and hair salons in Athens. These circumstances were improving to the income of refugees as well as the building of remittances from Europe to South Asian countries. Skill based labour force of South Asian refugees were filling the gaps of demand of skilled labourers in Greece. South Asian refugees were not legally working in Greece but also they were desired for legal migration to Western Europe with experiences of jobs and migration. These refugees were gaining their dreams in Europe because they migrated from South Asia to Europe with hopes of better life of themselves and their left behind family members in South Asia. Apart, they were emotionally attached with their left behind family members in their country in South Asia. They told that role of information technology like mobile and internet were the main source for communication to their left behind family members in South Asia. Mediums of social media likes Facebook and Whatsapp were minimising the geographical distance between South Asian refugees and their left behind family members as well as minimising the panic psychological conditions. ${ }^{12}$

South Asian refugees developed a cultural region of their homeland in Europe because they represented their South Asian culture by their languages, dress style, music and folk. South Asian music and digital news channels were so popular among South Asian refugees. These circumstances created an environment of South Asian culture in the environment of European culture. These South Asian refugees lived in the multi- linguistic pattern because they frequently used Greek language with their native South Asian languages. These consequences were developing a social and psychological bonding between South Asians refugees and Europeans. European society accepted to the presence of South Asian refugees because South Asian refugees were giving respect and honour to the solidarity of Europeans. These consequences were also creating social cohesion between South Asian refugees and

${ }^{10}$ The case study is based on the informal interview of south Asian refugee named Afjal at metro station of Athens on $25 / 08 / 2017$.

${ }^{11}$ The case study is based on the informal interview of south Asian refugee named Ahamad at metro station of Athens on $25 / 08 / 2017$.

${ }^{12}$ Information is based on the participant observation method among south Asian refugees with their focus group interview at parks of Omonoia square on 26/08/2017. 
Europeans in Greece. It is observed that South Asian refugees were integrating and associating with Europeans. These consequences were re-creating the identity of South Asians refugee due process of assimilation between South Asian and European culture. Europeans recognised and identified them as South Asian remaining their national identity of Pakistani and Bangladeshi. These circumstances sustained the cultural identity of South Asian refugees in the environment of European culture in Greece. ${ }^{13}$

It is observed that South Asian refugees were aware about rights of refugees under declaration of United Nation. These South Asian refugees were demanding political, social and economic rights with honour and respect under declaration of United Nation. It is observed that they organised meeting of South Asian refugees at parks in Athens in last week of every month whereby they discussed about their problems, challenges and opportunities. These South Asian refugees were digitally connected to each other in entire Europe as well as sensitive about emerging related issues about South Asian refugees in Europe. They considered opportunity of employment as rights of refugees. They expected a human centric approach from Europeans due to liberal policy of European Union about matters of refugees. They told that they were welcomed by Greece because they considered Greece as second home as well as gate way for enter in the developed Western Europe. They expressed that Europeans should not be worried about presence of South Asian refugees because south Asian refugees could be defined as alternative for fill the gap of labour markets in Europe. As a result, these South Asian refugees had positive attitudes about their presence in Europe with expectation of collaboration of world community regarding to the ensuring to rights of refugees in Europe. Therefore, it can be concluded that story of South Asian refugees were the synonyms of emotion, feeling, expectation and painful but they had strong positive attitudes about their status as Donki migrants in Europe. ${ }^{14}$

\section{Concluding Remarks and Suggestions}

Matters of South Asian refugees are emerged as global issues as well as give a perspective for explore to the Donki migration in broad sense. The term of Donki migration is associated with refugee of South Asia in Europe because they take risk of illegal migration from south Asia to Europe via route of Iran and Turkey. The findings of the study show that entire process of illegal migration from South Asia to Greece was led by both push and pull factors of migration. The lack of availability of the better economic opportunities in South Asia worked as push factor while availability of the better economic opportunities in Europe worked as pull factor in entire process of illegal Donki migration from South Asia to Greece in Europe. The well developed social network system from South Asia to Greece also worked as pull factor because social network system provided social and psychological support to illegal migrants in the route of long journey of illegal migration. The social network system provided information about hurdles of migration along with its solution to illegal migrants because they migrated in groups of Donki migrants; those were emotionally attached to each other and provided a positive energy to each other. They migrated with expectation of gain to better life and career in Europe. These positive expectations provided them a positive energy regarding to victory on the barriers of long journey of migration from South Asia to

\footnotetext{
${ }^{13}$ The information is based on participant observation method among south Asian refugees with their focus group interview at south Asian restaurant named Roti Boti in Athens on 27/08/2017.

${ }^{14}$ The information is based on the focus group interview of south Asian refugees at parks of Omonoia square in Athens on 28/08/2017.
}

Border Crossing 
Greece in Europe. These illegal migrants adopted the way of endless journey of migration because they did not have option to return to their homeland except to moving forward to one country to another country in Europe. They lived in the uncertain route of the migration because they were not confirmed about their exact destination in Europe. These illegal migrants considered to themselves as Donki migrants because this term provided geographical identity of South Asia as well as gave a positivity regarding sustaining to themselves in the endless journey of migration. These Donki migrants faced challenges and problems for getting status of convention refugee under provisions of UNHCR. These circumstances led to the illegal migration from Greece to countries of Western Europe because South Asian refugees considered Western Europe as most favourite destination compared to Greece. The South Asian refugees were engaged as skilled labourers in Athens because they used to work as convention refugee in Athens. The economic activity of South Asian refugees determined the economic identities of South Asian refugees as skilled labourers among Europeans.

These south Asian refugees faced problem of identities among Europeans because they were not easily accepted by Europeans due to unanswered question of identities of the South Asian refugees. Apart these, South Asian refugees had a great respect and honour for Europeans because Europeans gave a space to them for adjustment in the life of Europe. These South Asian refugees expected about better adjustment with Europeans because they considered Europeans as liberal society. These South Asian refugees adopted the little bit of European culture by language and cultural practices because South Asian refugees used to interact to Greek people in Greek language. These consequences developed a social and psychological bonding between Europeans and South Asian refugees because both South Asian refugees and Europeans easily understood the feeling of each other by Greek language. These South Asian refugees were represented the culture of South Asia by their languages, music, norms in their daily activities in Athens. There was well developed social bonding among South Asian refugees because they provided to social, economic and psychological support to each other in Greece as well as minimised the psychological panic condition of South Asian refugees in Greece. These South Asian refugees were connected with their left behind family members in South Asia because these refugees used mobile and internet for communicated to their left behind family members in South Asia. As a result, mode of modern communication minimised the psychological distress of the long geographical distance between South Asian refugees and their left behind family members in South Asia. The south Asian refugees expected respect and honour for their rights in Europe because they were aware about legal rights of refugees in Europe. They used to demand rights of employment from the European authority. They expected that European authority would not ignore the right of South Asian refugees in Greece. These South Asian refugees participated in group discussion and organised the meeting regarding discuss about issues of problems and challenges of rights of refugees in Greece.

On the basis of above concluding remarks, firstly, there is a required to start a broad study for explore to the process and determinants of Donki migration on the global level because such kinds of research can be helpful for making to the policy for ensuring to rights of refugees with rethinking about definition of refugee under economic perspective. Secondly, South Asian countries should start a comprehensive dialogue with European Union with collaboration with UNHCR to ensure the welfare and protection of South Asian refugees in Europe. Thirdly, South Asian countries should take a step to prevent the process of illegal 
Donki migration because illegal migrants are creating lots of challenges for themselves in the illegal route of migration. Fourthly, South Asian countries should start a skilled based training programme for South Asian migrants under monitoring of International Labour Organisation according to the demand of skills in Europe. These consequences can be helpful to lead legal migration from South Asia to Europe because South Asian refugees have capability to fill the gap of demand of labourers in the labour markets of Europe.

\section{References}

Aiyar, M. S., Barkbu, M. B. B., Batini, N., Berger, M. H., Detragiache, M. E., Dizioli, A. ... \& Topalova, P. (2016). The refugee surge in Europe: Economic challenges. International Monetary Fund.

Barslund, M., Lücke, M., \& Ruhs, M. (2019). Rethinking EU migration and asylum policies: Managing immigration jointly with countries of origin and transit. Stiftung MEDAM Assessment Report on Asylum and Migration Policies in Europe 2019 Mercator Dialogue on Asylum and Migration (MEDAM). Retrieved January 28, 2022, from Managing Immigration Jointly with Country of Origin and Transit: http://www.medam-migration.eu

Bilsborrow, R. E., Hugo, G., \& Oberai, A. S. (1997). International migration statistics: Guidelines for improving data collection systems. International Labour Organization.

Dogutas, A. (2019). Gender based violence against syrian refugee women in Turkey. Border Crossing, 9(2), 113-124.

Eren, E. Y. (2019). Is Temporary Protection Eternal? The Future of Temporary Protection Status of Syrians in Turkey. Border Crossing, 9(2), 125-134.

Foster, M., \& Lambert, H. (2016). Statelessness as a human rights issue: A concept whose time has come. International Journal of Refugee Law, 28(4), 564-584.

Gale, P. (2004). The refugee crisis and fear: Populist politics and media discourse. Journal of sociology, 40(4), 321-340.

Hatton, T. J., \& Williamson, J. G. (2006). Refugees, asylum seekers, and policy in Europe. In Labor mobility and the world economy (pp. 249-284). Springer, Berlin, Heidelberg.

Kesici, M. R. (2021). The History of Migration from Turkey to Western Europe: A Multi-theoretical Analysis of the Routes to Germany and the United Kingdom. Border Crossing, 11(2), 175-192.

Krzyżanowski, M., Triandafyllidou, A., \& Wodak, R. (2018). The mediatization and the politicization of the "refugee crisis" in Europe. Journal of Immigrant \& Refugee Studies, 16(1-2), 1-14.

Lamba, N. K., \& Krahn, H. (2003). Social capital and refugee resettlement: The social networks of refugees in Canada. Journal of International Migration and Integration/Revue de l'integration et de la migration internationale, 4(3), 335-360.

Ligabue, S. (2018). Forced Migration and Refugees: Truama Experiance and Participatory Care. Transnational Analysis Journal , 166-180.

McAuliffe, M. (2020). Migration and migrants: A global overview. Geneva: International Organization for Migration.

Nedoh, B. (2017). Mass migrations as a Messianic event? Rereading Agamben's State of exception in light of the Refugee crisis in Europe. Law, culture and the bumanities.

Obokata, T. (2010). Global governance and international migration: a case study of trafficking of human beings. Refugee Survey Quarterly, 29(1), 120-136.

Richmond, A. H. (2018). Sociological theories of international migration: the case of refugees. Current Sociology, 36(2), 7-25.

Robila, M. (2018). Refugees and Social Integration in Europe. New York : United Nations Department of Economic and Social Affairs Division for Social Policy and Development.

Rygiel, K., Baban, F., \& Ilcan, S. (2016). The Syrian refugee crisis: The EU-Turkey 'deal'and temporary protection. Global Social Policy, 16(3), 315-320.

Stevens, D. (2017). Asylum, refugee protection and the European response to Syrian migration. Journal of Human Rights Practice, 9(2), 184-189.

United Nation:Human Rights and Refugee Protection. (1995). Retrieved January 25, 2022, from right of refugees: http://www.unhcr.org/pdf

\section{Border Crossing}


Taukeer 43

United Nation:International Migration Report 2020_pdf. (2020). Retrieved January 25, 2022, from United Nation: Department of Economic and Social Affairs: http://www.un.org 